\title{
Virtual Education in Chile: An Example of a New Space for Learning
}

\author{
José Manuel Salum Tomé ${ }^{1}$ \\ ${ }^{1}$ Doctor of Education, Catholic University of Temuco, Chile \\ Correspondence: José Manuel Salum Tomé, PhD, Doctor of Education, Catholic University of Temuco, Chile. \\ E-mail: josesalum@gmail.com
}

Received: August 31, 2021

Accepted: September 28, 2021

Online Published: November 13, 2021

doi:10.20849/jed.v5i3.945

URL: https://doi.org/10.20849/jed.v5i3.945

\begin{abstract}
The Virtual Education was born in 2002 from a joint project between the Center for Improvement, Experimentation and Pedagogical Research CPEIP and the Center for Education and Technology Links.

CPEIP has developed a line of distance teacher training through the Internet running several courses since 2002, and Links during the last 15 years has dedicated its efforts to provide the access of teachers and students to educational opportunities associated with new technologies of Information and communication. Both institutions decided to combine their efforts and develop a joint project that integrates the CPEIP distance teacher training line, up to now aimed at curriculum updating, different strategies to support the appropriation of ICTs and their curricular integration.
\end{abstract}

Keywords: virtual education, virtual classrooms, ICT competencies, digital literacy

\section{Introduction}

Virtual education with e-learning and b-learning modality for teacher updating, is an initiative with coverage throughout the Chilean territory and is financed by the Ministry of Education of Chile through the Center for Improvement, Experimentation and Pedagogical Research (CPEIP). It has been developed by the Center for the Development of Innovations in Education. The training is inserted within the framework of the curricular reform, and incorporates ICT resources in the learning activities and teacher training.

This modality was born in the context of a line of teacher training with the support of a virtual component implemented by the CPEIP. On the other hand, a recent study carried out within the framework of the Links project shows that $92 \%$ of the establishments have technological infrastructure and $76 \%$ of the teachers have been trained in the use of ICT, the above as a result of the implementation of the project Links. On the other hand, penetration in the use of ICT in teachers is increasing by $80 \%$ of teachers with computers at home, $51 \%$ of them with Internet, $58 \%$ of them with broadband (Collect and Links 2004).

The development and implementation of the experience contemplated: a) the selection and training of tutors, b) the pedagogical design of the course, c) the design and implementation of the course on the Moodle platform; d) development of various content support resources, e) application of Pre and Post Test and summative and formative evaluations.

The course trained 786 teachers nationwide, divided into 29 courses, with an average of 27 students per course. For the tutorial support during the implementation of the course, a community of tutors was created to support them in their tasks of tutoring the course in the areas: administrative, technical, social and pedagogical. The work methodology placed the teacher at the center of learning, as an apprentice who autonomously defines their learning path. In this context, the participant builds knowledge through interaction with: the materials, the tutor and the classmates.

\section{Materials and Methods}

The development and implementation of the experience included:

The selection and training of tutors, for which the Salmon e-modetaring model was used, creating activities as learning objects. A profile was designed to select the tutors and they were trained through a course in the e-learning modality that concluded with a face-to-face meeting. 
Pedagogical design of the course, which has been conceived under an interactive model for the teaching of mathematics whose conception is very close to the expression of the Madison Project, which is synthesized in: "conjecture - try, put the idea to the test - observe what happens and ... learn how to continue ";

Design and implementation of the course on the Moodle platform ; It contemplated the organization of the contents in units, which have three areas: Activities and Evaluation : it finds the set of activities organized weekly, within the week by day and within the day, the specific activities with a brief description and time development estimate, considers a weekly formative assessment and a grade per unit; Interactions: includes a discussion forum, a space for consultations and a bulletin board; Library: groups the different resources such as readings, guides, Applets, reference material.

Development of various support resources contents: guides, reference materials, applets (component of an application running in the context of another program, for example in a web browser), readings, references to sites, among other resources.

The application of a Pre and Post Test: A pre-test was applied at the beginning of the course and a post-test at the end.

Obtaining and analyzing information such as: statistical data of participation in face-to-face, evaluations with qualifications on the platform and registration of participations in interactive spaces on the platform.

\section{Results and Discussion}

In this section the main results of the course are presented, they have been obtained through the different information registration systems such as: the application of the Pre and Post Test, attendance at face-to-face sessions, the results of the summative evaluations on the platform and the data obtained from the platform regarding participation in interactive spaces.

\subsection{Participation in the Course}

During every week a monitoring of the active students in the course was carried out, issuing a weekly report which gives an account of the number of active and inactive students in the week, in addition to counting those without any connection in the course.

In this section the main results of the course are presented, they have been obtained through the different information registration systems such as: the application of the Pre and Post Test, attendance at face-to-face sessions, the results of the summative evaluations on the platform and the data obtained from the platform regarding participation in interactive spaces.

\subsection{Participation in the Course}

During every week a monitoring of the active students in the course was carried out, issuing a weekly report which gives an account of the number of active and inactive students in the week, in addition to counting those without any connection in the course. Figure 7 shows the behavior of these parameters in the 14 weeks of course execution.

\subsection{Participation in Face-to-Face Sessions}

The course includes three face-to-face sessions, at the beginning, at the end of the course and after the first content unit. For the development of these face-to-face sessions, the tutor was given a plan to follow with the activities to be developed and digital resources as a presentation for their support.

\subsection{Participation in Face-to-Face Sessions}

The course includes three face-to-face sessions, at the beginning, at the end of the course and after the first content unit. For the development of these face-to-face sessions, the tutor was given a plan to follow with the activities to be developed and digital resources as a presentation for their support.

\subsection{Participation of Exchange Spaces}

This section will analyze the participation of the participants in the various asynchronous spaces contemplated for communication between the tutor with the students and between the participants themselves.

\subsection{Participation in Permanent Spaces}

The permanent spaces are a set of tools mainly forums that are available for use by participants throughout the course.

165 technical questions are presented an average of 5.5 per course. These doubts are related to the use of the platform and the configuration of the computers to run certain applications such as Applets. 
In the social forum there are 765 topics opened by the participants, within them there are different levels of interaction that are difficult to quantify, the average is 26.3 open topics per course, remember that these topics are initiated and encouraged by the participants themselves, existing null or void. little participation of the tutor, except in the welcome forum that the tutor starts in this space. The social forum becomes a kind of " virtual teachers room".

In news, space restricted to publications only by the tutor that cannot be debated by the participants, 624 interventions were recorded with an average of 21.5 interventions. These correspond to information and guidance that tutors send to their students regarding the development of activities, the rendering of evaluations and evaluation criteria, among others.

\subsection{Participation in Interactive Spaces}

Although participation in interactive spaces is variable in each unit, it follows similar trends that are later reflected in the overall three units, in this sense the discussion forum concentrates most of the interventions, followed by the daily wall forum and queries.

\section{Conclusions}

The course presented an effort to provide the teachers of the second cycle of primary education with a quality improvement process, which allows building the knowledge, both disciplinary and didactic, necessary for the participants to improve their pedagogical practices. The above in a distance modality that favors interaction with peers and the tutor within a learning community. The main conclusions are:

High interest in participating in the course: The interest shown by teachers to improve in Geometry has been reflected in the high numbers of enrolled and enrolled, which confirms the perceived need to train in this area. A total of 1,004 registered participants are registered.

Active students : The number of students who have remained active in the course is highly positive of the 1,004 original enrolled 786 gave the summative evaluation 1,78\% of effective participation, and between these and those who take the final evaluation there is a retention level of $83 \%$ of the participants. Additionally, an average of 670 participants connect weekly to the course, $85 \%$ of the active participants.

Valuation of the contents and resources: The contents of the course and the various resources that it provides have been valued by the participants, due to their quality, contextualization and the feasibility that they can use and transfer them to work in the classroom. Applets applications have been the most innovative within this set, as they simulate geometric constructions.

The face-to-face meetings The positive aspects of the face-to-face meetings focused mainly on the possibility of collaborative work, sharing experiences, increasing the sense of belonging and solving doubts associated with the methodology and the use of technology. The first face-to-face presented problems in its development due to the call and problems with the platform, the second was developed normally. The participants have suggested incorporating work directly related to the contents for future versions and some, despite being a distance course, suggest more face-to-face courses.

The platform: The platform has shown great stability, it only encountered problems at certain specific moments in the development of the course, mainly related to online questionnaires, in general terms it has been in a high operational and accessible percentage. The way in which the interactive spaces have been arranged are positively evaluated by the participants. They highlight its ease of use, they find it "friendly", the spaces you use frequently and they find them useful. In this sense, providing differentiated spaces for discussion, sharing resources, clarifying doubts and interacting on free topics such as the "social forum" we believe is an element that contributes to increasing the interaction and organize it. When participants are asked about the platform, they usually end up talking about the course and that is a signal that was made "invisible" to them, it merged into a single great element: the course.

The Interactions: An interesting use was made by the participants of the interactive spaces. Concerning the interventions in the discussion forums, 66\%, the "Bulletin Board" and "Queries" registered 28\% and 6\% respectively of the interventions. There was also a permanent space in which the social forum that monopolized the greatest participation from issues raised by the participants, transforming itself into a kind of "virtual teachers room". In this sense, we believe that the key to participation was to have established differentiated spaces for the types of interventions, which could channel the type of interventions that participants normally carry out in these courses, in addition to the animation of the tutor, especially in the discussion forum. 
Community of tutors: The community of tutors has been a space that has allowed the coordination of the pedagogical and tutorial team that coordinates the project with the tutors, through it has been possible to guide and support the tutors in the development of their work, The main spaces used have been: orientations, consultations, request for information and reports, as can be seen in the first two dedicated to pedagogical matters and the remaining two to administrative matters. An active role of tutors is observed in this community, especially those who achieve better results in their courses.

The tutors: The tutors are relevant agents in the development of the course, they have developed various tasks in the areas: pedagogical, social, technical and administrative. The role played by them especially at the beginning of the course to "charm" those who did not attend the classroom and at the times of the evaluations so that the students take them within the established deadlines has been vital to keep the students active. The work of these professionals has been highly valued by the participants, they perceive in them constant support in the development of the course and its activities as well as the clarification of pedagogical and administrative doubts, they perceive them close and always attentive to solving their doubts. A factor that has probably contributed are the weekly reports that were sent to them regarding the active and inactive participants of their course, this allows them to determine how their course is going in relation to their peers at the national level, several of them have received congratulations and recognition of the pedagogical team and their peers for the achievements .

Formation of the groups: In large regions such as the Metropolitan Region where the capital of the country is located, forming the groups according to the teacher's address, we believe that it is not the most optimal, since it transfers to the virtual environment the divisions that we carry out in the labor sphere. Teachers of establishments of poor communes with their peers and those of more affluent establishments with theirs. This from the perspective of the social construction of knowledge and Vigostky's Proximate Development Zone concept is not very adequate. In this sense, we believe that the participation of teachers from

Private establishments can become a contribution to the rest of the learning community, especially when they join groups from more popular sectors.

Evaluations: At a general and unit level, important advances in learning are observed, reflected in the differences in pre and post test. Additionally, the online summative evaluations also reflect these advances. A relevant element in our opinion is that the difference obtained in relation to the online summative tests and the pre and post test reflect that these are significantly closer to the post test, therefore they account for the learning acquired, overcoming mistrust initial in terms that these do not reflect individual learning since the teacher is presumed guilty of doing it with additional support to their own knowledge.

The process followed by the participating teachers has been largely successful, undoubtedly perfectible in various aspects. It has meant the development of a virtual teacher training experience that has given participants a new way of accessing content, quality materials and interaction with peers, tutor and specialists, on a subject that is a priority in the mathematical training of students. Chilean children like geometry. The experience of this course shows a way forward in these new forms of teacher updating that integrate the use of ICT as a channel of communication and training during professional life, giving access to a training experience that many of the participating teachers do not would have had access to the traditional face-to-face training formats.

\section{References}

Anderson, T., \& Kanuka, H. (1997). On-Line Forums: New Platforms for Professional Development and Group Collaboration. Journal of Computer- Mediated Communication (JCMC), 3(3). Retrieved October 31, 2003, from http://www.ascusc.org/jcmc/vol3/issue3/anderson.html

Barberà, E., \& Badia, A. (2004). Educating with virtual classrooms: Orientations for innovation in the teaching and learning process. Madrid: A. Machado.

Bates, A. W. (1995). Technology open learning and distance education. London/NewYork: Routledge.

Berge, Z. L. (1995). Facilitating Computer Conferencing: Recommendations From the Field. Educational Technology, 35(1), 22-30. Retrieved August 18, 2003, from http://www.emoderators.com/moderators/teach_online.html

Braslavsky, C. (1999). Bases, guidelines and criteria for the design of teacher training programs. Inter-American Journal of Education, (19), 13-50. Madrid-Spain: Organization of Ibero-American States for Education, Science and Culture (OEI). Retrieved July 22, 2003, from http://www.campus-oei.org/oeivirt/rie19.htm

Bultron, C. (2000). New trends in education. World Report on Communication and Information 1999-2000 (pp. 51-67). UNESCO/CINDOC editions. 
Cabero, J. (2001). The application of ICT: snobbery or educational need?. Red Digital [ online], 1. Retrieved December 22, 2002, from http://reddigital.cnice.mecd.es/1/firmas/firmas_cabero_ind.html

Coll, C. (2001). Constructivism and education: the constructivist conception of teaching and learning. In Coll, C., Palacios, J., \& Marchesi, A. (Eds.), Psychological Development and Education II. Educational Psychology (pp. 157-186). Madrid: Alliance.

Collect \& Links. (2004). Survey: Education in the Information Society. Links Statistics 2005 (pp. 9-22). Retrieved May 15, 2005, from http://www.enlaces.cl/libro/encuesta.pdf

Crook, C. H. (1998). Computers and collaborative learning. Madrid: Morata / MEC Ministry of education and culture (Original title: Computer and the collaborative experience of learning, London: Routledge, 1994).

Greening, T. (1998). Building the constructivist toolbox: an exploration of cognitive technologies. Educational Technology, 38(2), 23-35.

Gros, B. (2002). Constructivism and designs of virtual learning environments. Revista de Educación, 328, 225-247.

Gros, B., \& Silva, J. (2005). Teacher training as teachers in virtual learning spaces. Revista Iberoamericana de Educación, 36(1). Retrieved from http://www.campus-oei.org/revista/tec_edu32.htm

Grünberg, J. (2002). REDOCENTE: an investigation on electronic collaboration between mathematics and science teachers. New Technologies in Education. Montevideo, Uruguay University of the Republic. Retrieved December 13, 2003, from http://www.prc- antel.org.uy/nte/on-line/modulo_3.htm\#3

Harasim, L., Hiltz, S., Turoff, M., \& Teles, L. (2000). Learning networks: Guide for teaching and learning online. Barcelona: Gedisa / EDIUOC [Original version] Learning networks. A faithful guide to teaching and learning online. Cambridge (USA): Massachusetts Institute of Technology Press, 1995.

Hernández, P. (1997). Building constructivism: criteria for its foundation and school application. In Rodrigo, $\mathrm{M}^{\mathrm{a}}$.J. Arnay, J. (Ed.), The construction of school knowledge (pp. 285-312). Barcelona / Buenos Aires / Mexico: Paidós.

Pérez, A. (2002). Elements for the analysis of educational interaction in new learning environments. pixel-bit media and education magazine [online], 19. Retrieved April 1, 2003, from http://www.sav.us.es/pixelbit/articulos/n19/n19art/art1904.htm

Ryan, S., Scott, B., Freeman, H., \& Patel, D. (2000). The virtual university: the Internet and resource -based learning. London: Kogan Page.

Salmon, G. (2000). E-moderating: The key to teaching and learning online. London: Kogan Page.

Swan, K., Shea, P., Fredericksen, E., Pickett, A., Pelz, W., \& Maher, G. (2000). Building knowledge building communities: consistency, contact and communication in virtual classroom. Journal Educational Computing Research, 23(4), 359-381.

Vygostky, L. S. (1978). The development of higher psychological processes. Barcelona: Critique.

\section{Copyrights}

Copyright for this article is retained by the author(s), with first publication rights granted to the journal.

This is an open-access article distributed under the terms and conditions of the Creative Commons Attribution license (http://creativecommons.org/licenses/by/4.0/). 